\title{
POJEDNANIE POKRZYWDZONEGO ZE SPRAWCA JAKO PODSTAWA DO UMORZENIA POSTĘPOWANIA W ŚWIETLE PROJEKTU KOMISJI KODYFIKACYJNEJ PRAWA KARNEGO
}

Obecnie trwaja prace legislacyjne nad projektem nowelizacji Kodeksu postępowania karnego i niektórych innych ustaw, w którym przewiduje się dodanie do ustawy z 6 czerwca 1997 r. Kodeks karny ${ }^{1}$ art. 59a w brzmieniu następującym: „Na wniosek pokrzywdzonego umarza się postępowanie karne o występek zagrożony karą nieprzekraczającą 5 lat pozbawienia wolności, jeżeli przed rozpoczęciem przewodu sądowego w pierwszej instancji sprawca pojednał się, w szczególności w wyniku mediacji, z pokrzywdzonym i naprawił szkodę wyrządzoną przestępstwem lub zadośćuczynił wyrządzonej krzywdzie”. Przepis ten nakazuje umorzenie postępowania karnego w przypadku, gdy sprawca nie tylko pojednał się z pokrzywdzonym, lecz także naprawił szkodę wyrządzona przestępstwem lub zadośćuczynił wyrządzonej krzywdzie. Jednocześnie przyznaje pokrzywdzonemu decydująca rolę, albowiem od jego zgody zależeć będzie, czy prokurator w postępowaniu przygotowawczym, a sądowym - sąd, wyda decyzję umarzająca postępowanie. W uzasadnieniu projektu wskazuje się, że dzięki tej regulacji ,,z procesu karnego w szybszy sposób będą eliminowane sprawy, których prowadzeniem nie jest zainteresowany sam pokrzywdzony, z uwagi na zakończenie sporu, a do uczestniczenia w których byłby jednak zobowiązany bez wprowadzenia tej instytucji" 2 .

Już na wstępie oceny merytorycznej zaproponowanej instytucji należy zauważyć, że stanowi ona przejaw oportunizmu procesowego, który może być wyjątkiem od zasady legalizmu, o ile znajduje uzasadnienie w celach, jakie ma realizować Kodeks postępowania karnego z 1997 r.; cele te zgodnie z uzasadnieniem projektu tego Kodeksu zdefiniować można jako „,racjonalne usprawnienie postępowania karnego, uczynienie go bardziej skutecznym oraz szybszym i tańszym sposobem zwalczania drobnej i średniej przestępczości, umożliwiając tym samym koncentrację sił i środków do zwalczania przestępstw najpoważniejszych, szczególnie niebezpiecznych dla porządku społecznego i bezpieczeństwa państwa"3. Z przypadkami oportunistycznego zakończenia

\footnotetext{
${ }^{1}$ Dz. U. Nr 88, poz. 553.

${ }^{2}$ Projekt ustawy z 5 czerwca 2012 r. o zmianie ustawy - Kodeks karny, Kodeks postępowania karnego i niektórych innych ustaw wraz z uzasadnieniem dostępny na: big.ms.gov.pl.

${ }^{3}$ Uzasadnienie rządowego projektu nowego Kodeksu postępowania karnego: Kodeks karny - Kodeks postępowania karnego - Kodeks karny wykonawczy - z uzasadnieniami, Warszawa 1997, s. 393.
} 
postępowania spotykamy się w Niemczech, gdzie odnotować można silne oddziaływanie zasady legalizmu, a także w Belgii, Holandii, Danii, Norwegii, Luksemburgu czy we Francji ${ }^{4}$. Oportunistyczne zaniechanie ścigania karnego rekomenduje także Rada Europy (Council of Europe, The Simplification of Criminal Justice, Recommendation $\mathrm{nr}$ R(87)18, Strasbourg 2000, s. 21), zajmując stanowisko, że państwa członkowskie mogą ograniczyć postępowanie sądowe, uniknąc postępowań karnych w sprawach, gdy nie są one konieczne z punktu widzenia interesu publicznego, zapewnić szybsza i bardziej odpowiednią reakcję na przestępstwo, co leży także w interesie ofiary.

Należy nadmienić, że zasada legalizmu nie jest dzisiaj rozumiana jako nakaz wymierzenia kary w sprawie o każde przestępstwo, w myśl zasady nullum crimen sine poena, lecz jako obowiazek adekwatnej reakcji organów procesowych na popełnione przestępstwo. Stąd sytuacja, w której sprawca czynu nie zostanie ukarany $\mathrm{w}$ wyniku sięgnięcia przez organy ścigania po instytucje pozwalające na rezygnacje $\mathrm{z}$ ukarania sprawcy, nie przeczy tej zasadzie.

$\mathrm{Z}$ pewnością projekt ten stanowi wzmocnienie funkcji restytucyjnej, której doniosłość nabrała znaczenia wraz $\mathrm{z}$ wejściem w życie nowego Kodeksu karnego, na gruncie którego przestępstwo przestało być postrzegane przede wszystkim jako konflikt między jego sprawca a społeczeństwem, a stało się także konfliktem między sprawcą a ofiarą. Z tego punktu widzenia wydaje się, że koncepcja zaproponowana przez Komisję Kodyfikacyjną mogłaby zasługiwać na aprobatę. Niemniej jednak budzi pewne zastrzeżenia, i to już na płaszczyźnie realizacji funkcji i celów prawa karnego.

Truizmem jest twierdzenie, że prawo karne ma do spełnienia także inne równie ważne powinności, wśród których priorytetem jest ochrona dóbr uznanych przez ustawodawce za cenne, i to nie tylko z punktu widzenia interesów poszczególnych obywateli, lecz całego społeczeństwa ${ }^{5}$. W tym stanie rzeczy należałoby się zastanowić, czy przestępstwo popełnione przeciwko dobrom indywidualnym nie jest jednocześnie pośrednio wymierzone także w dobra ogółu. W końcu nawet naruszenie reguł gospodarczych i wyrządzenie szkody podmiotowi gospodarczemu pociagnie za sobą negatywne konsekwencje $\mathrm{u}$ jego partnerów finansowych i wierzycieli. Analizując zatem proponowana instytucję, nasuwa się wątpliwość, czy pojednanie pokrzywdzonego ze sprawca jest wystarczającym - z punktu widzenia zabezpieczenia dóbr prawnych społeczeństwa - argumentem za rezygnacją z karania.

Wreszcie, funkcja ochronna może być spełniona jedynie, gdy prawo karne będzie motywowało sprawcę do przestrzegania prawa. W końcu na płaszczyźnie funkcji ochronnej ważne jest, by sprawca przestępstwa ponownie nie popełnił. Dlatego też w świadomości sprawcy powinno egzystować przekonanie, że atak na społeczne wartości pociąga za sobą zastosowanie przewidzianej w ustawie kary. Sprawca atakujący dobro prawne musi mieć świadomość nieuchronności sankcji karnej, a to zagrożenie karą musi być rzeczywiste. Dokonując jednak

\footnotetext{
${ }^{4}$ M. Rogacka-Rzewnicka, Oportunizm i legalizm ścigania przestępstw $w$ świetle wspótczesnych przeobrażé procesu karnego, Warszawa 2007, s. 129.

${ }^{5}$ A. Marek, Prawo karne, Warszawa 2011, s. 14.
} 
oceny merytorycznej proponowanego rozwiązania, można mieć wątpliwości, czy nałożenie na sprawcę jedynie obowiązku pojednania się z pokrzywdzonym może stanowić przeciwmotyw do podjęcia bezprawnego zachowania w przyszłości. Na tym tle rodzi się pytanie, jakie moga być konsekwencje faktu, że sprawca ma świadomość, iż pociągnięcie go do odpowiedzialności karnej zależy jedynie od woli pokrzywdzonego ${ }^{6}$. Czy świadomość, że naprawienie szkody nawet w części może być podstawą do zakończenia postępowania i uniknięcia odpowiedzialności karnej nie zachęci sprawcy do przestępnej działalności? A co więcej, czy wynikiem proponowanej instytucji nie będzie kalkulacja zysków i strat zachowania niezgodnego z prawem?

Proponowana instytucja przeczy także najstarszej funkcji prawa karnego: funkcji sprawiedliwościowej, która wzmacnia w odczuciu społecznym przekonanie, że zło jest piętnowane. W końcu rolą prawa karnego jest takie karanie sprawców przestępstw, które utwierdza autorytet prawa, przez co oddziałuje korzystnie zarówno na sprawcę, jak i na społeczeństwo. Ustawodawca opowiada się za potrzebą kształtowania świadomości prawnej społeczeństwa i uważa prewencję generalną za jedną z ogólnych dyrektyw sądowego wymiaru kary. Tym samym fakt wymierzenia kary za przestępstwo ma oddziaływać nie tylko na sprawcę, lecz także na innych potencjalnych sprawców przestępstw. Nie ulega także wątpliwości, że niestosowanie sankcji karnych w niektórych przypadkach może stanowić czynnik demoralizujący i jednocześnie zachęcający potencjalnych sprawców do naruszenia prawa ${ }^{7}$.

Wiadomo, że społeczna potrzeba karania może podlegać pewnym modyfikacjom, chociażby $\mathrm{z}$ uwagi na zachowanie sprawcy po popełnieniu przestępstwa, niemniej jednak organy ścigania powinny mieć możliwość oceny tego zachowania. Tymczasem w przypadku proponowanego rozwiązania sąd będzie pozbawiony jakiejkolwiek możliwości oceny. Okoliczność ta budzi wątpliwości, tym bardziej jeżeli weźmiemy pod uwagę, że naprawienie szkody i pojednanie się z pokrzywdzonym nie zmniejszają stopnia winy sprawcy i społecznej szkodliwości czynu. Wydaje się więc, że pożądana byłaby ocena zachowania sprawcy z punktu widzenia celów, jakie powinna osiągać kara w zakresie prewencji indywidualnej i ogólnej ${ }^{8}$. W doktrynie słusznie wskazuje się, że samo przywrócenie stanu poprzedniego czy zobowiązanie się do naprawienia szkody to jedynie konsekwencje popełnienia czynu zabronionego, dopiero zaś rzeczywista chęć zadośćuczynienia za wyrządzoną krzywdę może stanowić okoliczność uwzględnianą przy wymiarze kary ${ }^{9}$. Biorąc jednak pod uwagę motywy, jakimi kierować będzie się oskarżony, gdy zdecyduje się naprawić szkodę w ramach instytucji z art. 59a, trudno w tym przypadku mówić o procesie motywacyjnym zasługującym choćby na nadzwyczajne złagodzenie kary.

\footnotetext{
${ }^{6}$ W. Wróbel, A. Zoll, Polskie prawo karne. Część ogólna, Kraków 2010, s. 40 i n.

${ }^{7}$ W. Wróbel, w: G. Bogdan et al. (red.), Kodeks karny. Część ogólna. Komentarz, t. 1: Komentarz do art. 1-116 K.k., Kraków 2004, s. 831.

${ }^{8}$ Wyrok SA w Krakowie z 17 września 1992 r., II Akr 158/92, KZS 1992, z. 10, poz. 10; wyrok SA w Krakowie z 24 czerwca 1996 r., II AKa 121/96, KZS 1996, z. 7-8, poz. 49.

${ }^{9}$ W. Wróbel w: G. Bogdan et al. (red.), op. cit., s. 853.
} 
Pewne zastrzeżenia nasuwaja się także na płaszczyźnie realizacji celów postępowania karnego. Artykuł $2 \S 1$ k.p.k. poza tym, że uwzględnia prawnie chronione interesy pokrzywdzonego, wskazuje bowiem na jeszcze inne cele postępowania karnego. Zgodnie z § 1 pkt 2 postępowanie karne zmierza nie tylko do prawidłowego zastosowania prawa karnego materialnego $\mathrm{w}$ konkretnej sprawie, lecz także spełniać ma określone zadania wychodzące poza te ramy. Chodzi o to, aby stosować przepisy postępowania karnego w taki sposób, by stworzyć optymalne warunki realizacji profilaktyki w sferze zapobiegania przestępstwom, a także umacniania poszanowania prawa i zasad współżycia społecznego ${ }^{10}$. Założeń tych nie będzie spełniać projektowana instytucja.

Abstrahując od powyższego, zauważyć należy, że treść art. 59a przewiduje regulację, która w gruncie rzeczy niejako pozwala na ,wykupienie się” oskarżonego od odpowiedzialności karnej: wystarcza, że o umorzenie postępowania wniosek złoży pokrzywdzony, a to ze względu na pojednanie się ze sprawca i naprawienie przez niego wyrządzonej szkody. Z tym że przepis nie wskazuje, w jakiej wysokości szkoda ta musi zostać naprawiona, ani nie wymaga od sprawcy naprawienia jej w całości. W praktyce to pokrzywdzony decydować będzie, czy zadośćuczynienie lub naprawienie szkody ze strony sprawcy jest wystarczające i może być podstawą do uznania, że zachodzi brak potrzeby wymierzenia kary. To od pokrzywdzonego zależeć będzie, czy postępowanie wszczęte $\mathrm{w}$ wyniku popełnienia czynu zabronionego ma być zakończone bez orzekania o winie i karze, czy będzie kontynuowane do wydania wyroku. Takie rozwiązanie pozostaje jednak w konflikcie z realizacją konstytucyjnej wyłącznej kompetencji sądu do sprawowania wymiaru sprawiedliwości. Z drugiej strony uzależnienie skazania jedynie od decyzji pokrzywdzonego może doprowadzić do tego, że lęk i strach przed oskarżonym będą wystarczającym pretekstem do złożenia wniosku w trybie art. 59a k.k.

Ponadto $\mathrm{w}$ praktyce takie rozwiązanie spowoduje, że odpowiedzialność karna sprawcy uzależniona będzie od jego statusu materialnego. Tymczasem w orzecznictwie można zaobserwować tendencję do surowszej oceny przestępstw popełnianych przez sprawców o wysokim statusie społecznym ${ }^{11}$. Zdaniem zaś doktryny status społeczny sprawcy „może być brany pod uwagę jako okoliczność związana z prewencyjnym oddziaływaniem kary. Sprzeczne z prawem działania osób, które z uwagi na pełnione funkcje społeczne faktycznie kształtują wzorce zachowań społecznych, mogą pociagać za sobą wyższy poziom zagrożenia dla poczucia obowiązywania norm prawnych, a tym samym w wyższym stopniu przyczyniać się do destrukcji obowiązujących wartości społecznych. Może to uzasadniać potrzebę surowszej reakcji karnej, nieprzekraczającej wszakże stopnia winy" ${ }^{12}$.

Największe zastrzeżenia budzi jednak fakt, że instytucja ta wprowadza obligatoryjne umorzenie postępowania. Jak wiadomo, jest to sposób na zakoń-

${ }^{10}$ P. Hofmański, w: idem, E. Sadzik, K. Zgryzek, Kodeks postępowania karnego. Komentarz do art. 1-296, t. 1, wyd. 4, Warszawa 2011, Komentarz do art. 2 k.p.k. (dostępny w systemie informacji prawnej Legalis).

11 Wyrok z 23 stycznia 1992 r., II Akr 164/91, KZS 1992, z. 2, poz. 15; wyrok SA w Krakowie z 17 grudnia 2001 r., II AKa 186/01, KZS 2002, z. 6, poz. 14.

${ }^{12}$ W. Wróbel, G. Bogdan et al. (red.), op. cit., s. 846. 
czenie postępowania $\mathrm{w}$ sytuacji, gdy nie ma potrzeby orzekania o winie i karze oskarżonego. Obecnie taki sposób zakończenia postępowania wskazany jest między innymi, gdy czynu nie popełniono albo brak danych dostatecznie uzasadniających podejrzenie jego popełnienia lub gdy czyn nie zawiera znamion czynu zabronionego albo ustawa stanowi, że sprawca nie popełnia przestępstwa. Ustawodawca przewiduje więc taką samą konsekwencję prawną $\mathrm{w}$ warunkach wskazanych $\mathrm{w}$ art. 17 k.p.k. jak w sytuacji, gdy sprawca występku zagrożonego kara nieprzekraczająca 5 lat pozbawienia wolności pojednał się z pokrzywdzonym i wyrządzoną mu szkodę naprawił. Tym samym w ocenie projektodawców pojednanie się z pokrzywdzonym i naprawienie szkody skutkuje tym, że czyn zagrożony kara 5 lat pozbawienia wolności prowadzi do znikomej społecznej szkodliwości czynu (pkt 3 art. $17 \S 1$ k.p.k.). $\mathrm{Z}$ pewnością wprowadzenie mechanizmu oportunizmu procesowego $\mathrm{w}$ postaci zaprezentowanej przez projektodawcę już na tym tle jawi się jako zbyt daleko idące.

Po wtóre, ustawodawca wprowadzając instytucję umorzenia postępowania, nie uzależnia jej zastosowania od charakteru dobra prawnego, przez co będzie ona mogła mieć zastosowanie nawet w przypadku niektórych umyślnych przestępstw przeciwko zdrowiu i życiu, czy przestępstw przeciwko rodzinie i opiece. Rodzi się jednak pytanie, czy taka ewentualność powinna obejmować wszystkie rodzaje czynów, czy może należałoby ją ograniczyć jedynie do wąskiej grupy przestępstw. Wydaje się wręcz, że taki sposób zakończenia postępowania można byłoby wprowadzić jedynie w przypadku zamachu na określone dobra prawne.

Wreszcie nasuwa się pytanie o potrzebę wprowadzenia takiej konstrukcji do Kodeksu karnego. Instytucja postępowania mediacyjnego pomiędzy pokrzywdzonym a sprawca została już przewidziana w art. 23a k.p.k. Należy także mieć na uwadze, że od pojednania ustawodawca uzależnia niekiedy stosowanie warunkowego umorzenia postępowania karnego (art. 66 § 3 k.k.) i nadzwyczajnego złagodzenia kary (art. $60 § 2$ k.k.). Ustawodawca nakazuje uwzględnienie wyników mediacji pomiędzy pokrzywdzonym i sprawcą również przy wymiarze kary (art. $53 \S 3$ k.k.). Nie można także podzielić opinii, że wprowadzone rozwiązanie będzie niezastąpione w przypadku występków skierowanych przeciwko mieniu ${ }^{13}$. Obecnie obowiązujący Kodeks karny przewiduje już bowiem podobne rozwiazanie, które co prawda nie pozwala na umorzenie postępowania wobec sprawcy przestępstwa przeciwko mieniu, ale umożliwia nadzwyczajne złagodzenie lub odstapienie od wymierzenia mu kary (art. 295 k.k.).

Jeśli nawet zaakceptuje się potrzebę wprowadzenia takiej konstrukcji do ustawy, nie można się zgodzić z jego usytuowaniem w Kodeksie karnym proponowanym przez ustawodawcę. Projektowany przepis (art. 59a) planuje się bowiem umieścić w rozdziale VI Kodeksu karnego, zatytułowanym „Zasady wymiaru kary i środków karnych”. Rozdział ten zawiera zasady sądowego wymiaru kary, która łączy się z konstytucyjną zasadą niezawisłości

13 Uzasadnienie projektu. 
sędziowskiej, gwarantującą sędziom pełną niezależność przy orzekaniu. Zasada ta oznacza swobodę decyzji w przedmiocie wyboru rodzaju reakcji prawnokarnej na czyn sprawcy. Tymczasem projektowany przepis, wprowadzając nakaz obligatoryjnego umorzenia postępowania, wyłącza decyzje sądu odnośnie do innego rozstrzygnięcia sprawy i jednocześnie przekazuje decyzje o potrzebie karania jedynie w ręce pokrzywdzonego. Co więcej, przepis ten będzie wiązał ręce sądom $\mathrm{w}$ takim stopniu, w jakim nie czyni tego nawet $\mathrm{w}$ przypadku instytucji skazania bez rozprawy (art. 335 k.p.k.) czy rozprawy skróconej (art. 387 k.p.k.), kiedy to decyzja o sposobie ostatecznego rozstrzygnięcia sprawy pozostaje jednak w gestii sądu. W związku z powyższym umieszczenie tego przepisu wśród przepisów przyznających sądowi wymierzenie kary według swego uznania jest nieporozumieniem, albowiem przepis ten jest podstawa, która całkowicie wyłącza decyzyjność sądu w tym zakresie.

Można by więc zaproponować taką modyfikację tej instytucji, która zamiast konieczności umorzenia postępowania dawałaby jedynie możliwość takiego zakończenia sprawy, a o jej zastosowaniu ostatecznie decydowałby sąd. Zmiana ta pozwalałaby sądom na ocenę, czy w konkretnym przypadku umorzenie postępowania jest zasadne, biorąc pod uwagę rodzaj naruszonego lub zagrożonego dobra prawnego, lub czy zachodzi potrzeba ukarania sprawcy z punktu widzenia podstawowych funkcji norm karnych oraz celów postępowania karnego. Niemniej jednak trzeba stwierdzić, że wprowadzenie fakultatywnego charakteru tej instytucji będzie czyniło ją bezużyteczną, gdyż sprawca i tak do końca nie będzie wiedział, czy naprawiając szkodę, może liczyć na jej zastosowanie. Nadto fakultatywny charakter tej instytucji przybliży podstawę jej zastosowania do znikomej społecznej szkodliwości czynu, której wystąpienie jest podstawą umorzenia postępowania zgodnie $\mathrm{z}$ art. 17 k.p.k.

Wreszcie należy zauważyć, że dojście do skutku pojednania pomiędzy pokrzywdzonym a sprawca, przeprowadzonego na skutek postępowania mediacyjnego, czy fakt naprawienia szkody albo uzgodnienie przez pokrzywdzonego i sprawcę sposobu jej naprawienia decydują o samej dopuszczalności instytucji warunkowego umorzenia postępowania (art. $66 \S 3$ k.k.) ${ }^{14}$. Nie ma więc powodów, by pojednanie się ze sprawcą również nie prowadziło w tym przypadku do umorzenia postępowania, ale dokonywanego warunkowo. Rozwiązanie to wydaje się słuszne dlatego, że w razie warunkowego umorzenia postępowania sąd jedynie odracza wydanie rozstrzygnięcia co do winy i odpowiedzialności karnej. Z drugiej strony wyrok taki byłby także korzystny dla oskarżonego, ponieważ orzeczenia takiego nie rejestruje się w Krajowym Rejestrze Karnym jako skazania ${ }^{15}$.

${ }^{14}$ Dotyczy to przestępstwa zagrożonego karą przekraczająca 3 lata i nieprzekraczająca 5 lat pozbawienia wolności.

${ }^{15}$ Już właściwszym rozwiązaniem od obecnej propozycji byłoby, aby przepis ten skutkował zastosowaniem instytucji odstąpienia od wymierzenia kary, które jednak w przeciwieństwie do warunkowego umorzenia postępowania ma charakter wyroku skazującego. W tym przypadku jednak sytuacja sprawcy byłaby mniej korzystna, niż przewiduje to warunkowe umorzenie postępowania, co z pewnością stanowiłoby mniejszą zachętę do pojednania się z pokrzywdzonym. 
Uwzględniwszy wszystkie powyżej poczynione uwagi, uznać należy, że przeprowadzona analiza konstrukcji i treści nowego przepisu proponowanego przez Komisję Kodyfikacyjną w swej obecnej postaci pozwala na krytyczna jego ocenę.

Porównując proponowaną instytucję $\mathrm{z}$ możliwościami zawartymi w niemieckim kodeksie postępowania karnego (StPO), należy zauważyć, że w prawie niemieckim istnieje instytucja oportunistycznego umorzenia podstępowania karnego, zwana ,umorzeniem po spełnieniu nałożonych obowiązków” ( $\$ 153 \mathrm{a}$ StPO). Wprowadzenie tej instytucji wynikało $\mathrm{z}$ potrzeby zwiększenia efektywności w zakresie ścigania cięższych przestępstw przez odciążenie organów ścigania od obowiązku prowadzenia postępowań w sprawach drobniejszych i podyktowane było względami ekonomiki procesowej ${ }^{16}$. Cel wprowadzenia tej konstrukcji jest więc tożsamy $\mathrm{z}$ argumentami przemawiającymi za wprowadzeniem do polskiej ustawy karnej art. 59a. Różnica, i to znaczna, pojawia się jednak w samej konstrukcji i treści obu tych instytucji.

Regulacja § 153a została umieszczona wśród przepisów księgi II rozdziału I niemieckiego k.p.k. (StPO), który zawiera przypadki dopuszczalności odstąpienia od ścigania karnego. Przepis ten stanowi, że w przypadku występków prokuratura może, za zgodą właściwego sądu oraz za zgodą oskarżonego, tymczasowo zaniechać wnoszenia oskarżenia publicznego i równocześnie nałożyć na oskarżonego obowiązki przewidziane w ust. 1 tego przepisu, pod warunkiem że takie rozstrzygnięcie nie narusza interesu publicznego oraz waga czynu, stopień winy są niewielkie. Odstapienie od postępowania ma charakter warunkowy i zależy od wywiązania się przez sprawcę z nałożonych na niego zobowiązań procesowych. Warunki zastosowania tej instytucji obejmują różne formy naprawienia szkody wyrządzonej przestępstwem, które skutkują umorzeniem postępowania. Warto podkreślić, iż niewypełnienie przez oskarżonego nałożonych na niego obowiązków powoduje, że przestępstwo nie może być na dalszym etapie ścigane jako mniej poważne ${ }^{17}$. W sytuacji gdy akt oskarżenia został już wniesiony do sądu, o zastosowaniu tej instytucji orzeka za zgodą prokuratury i oskarżonego - sąd.

Do największych różnic w regulacji polskiej i niemieckiej zaliczyć można fakt, że umorzenie na gruncie StPO może mieć miejsce już na etapie postępowania przygotowawczego. W przeciwieństwie do polskiej propozycji rozwiązanie niemieckie ma zastosowanie jedynie do czynów zagrożonych kara pozbawienia wolności do 1 roku lub kara grzywny. Jakkolwiek obie instytucje prowadzą do zakończenia postępowania, to regulacja niemiecka posiada cechy polskiego warunkowego umorzenia postępowania, jako że do czasu spełnienia przez podejrzanego nałożonych przez prokuratora obowiązków istnieje tylko warunkowa przeszkoda procesowa kontynuowania postępowania. Także w niemieckiej doktrynie instytucję tę określa się czasem mianem bedingte Einstellung, a więc warunkowym umorzeniem, mimo że częściej używaną

${ }^{16}$ U. Hellmann, Strafprozeßrecht, Berlin-Heidelberg 1998, s. 262.

${ }^{17}$ M. Rogacka-Rzewnicka, Oportunizm i legalizm ścigania przestẹstw $w$ świetle wspótczesnych przeobrażé́ procesu karnego, Warszawa 2007, s. 100; J. Schulenburg, Zasady legalizmu i oportunizmu $w$ niemieckim kodeksie postępowania karnego - zależności i sprzeczności, „Prokuratura i Prawo” 2003, nr 5, s. 96 i n. 
nazwą tej regulacji jest vorläufige Einstellung (,tymczasowe umorzenie”). $\mathrm{W}$ doktrynie niemieckiej wskazuje się, że takie rozwiązanie nie narusza zasady legalizmu, gdyż odstąpienie od ścigania z powodu nieznacznej wagi czynu jest uwarunkowane określonymi przesłankami i nie jest pozostawione swobodnemu uznaniu organów ścigania ${ }^{18}$.

Podobna regulacja występuje we francuskim postępowaniu karnym art. 41-1 CIC (Code d'instruction criminelle). Na jej podstawie prokurator może wezwać sprawcę do wykonania określonych obowiązków, w tym także do naprawienia szkody wyrządzonej przestępstwem. W razie niewykonania przez sprawcę przestępstwa obowiązków nałożonych przez prokuratora ten ostatni może wszcząć śledztwo albo zaproponować zawarcie porozumienia (composition pénale ${ }^{19}$. Wykonanie przez sprawcę obowiązków nałożonych przez prokuratora $\mathrm{w}$ ramach zawartego porozumienia prowadzi do umorzenia postępowania karnego. Podobnie jak w proponowanym polskim rozwiązaniu wymienione porozumienie stosowane jest $\mathrm{w}$ razie popełnienia występku zagrożonego kara pozbawienia wolności do lat 5 , z tym że wymaga zgody prezesa sądu lub upoważnionego sędziego.

W obu tych przypadkach ustawodawca europejski zdecydował się jednak na wprowadzenie instytucji umorzenia postępowania już na etapie postępowania przygotowawczego. W wyniku takiego rozwiązania znaczny odsetek spraw z zakresu drobnej przestępczości nie jest kierowany do sądu. Wydaje się, że i na gruncie polskiej ustawy karnej zasadne jest wprowadzenie nowej instytucji, która wzorowałaby się na niemieckiej i francuskiej procedurze karnej. Zmiany te byłyby zgodne z sugestią Rady Europy, która w rekomendacji podniosła, że „dzięki wprowadzeniu zasady swobody decyzyjnej w postępowaniu prokuratorskim państwa członkowskie mogą: ograniczyć presję na system sądownictwa; uniknąć postępowań karnych w sprawach, w których nie były one konieczne z punktu widzenia interesu społecznego; zapewnić szybszą i odpowiednią reakcję na przestępstwo, co leży również w interesie ofiary; czynić jak najlepszy użytek z dostępnych środków" ${ }^{20}$.

Takie kierunki zmian były już wysuwane na gruncie polskiej procedury karnej. Tytułem przykładu można tu podać pogląd A. Murzynowskiego, w ocenie którego celowe byłoby objęcie bezwarunkowym umorzeniem postępowania przygotowawczego w przypadku zawarcia ugody między pokrzywdzonym i oskarżonym, jeśli jej wykonanie nastąpiło w całości w toku postępowania przygotowawczego $^{21}$. Autor ten, uzasadniając swoje stanowisko, wskazał, że co prawda regulacja taka będzie odstępstwem od zasady legalizmu na rzecz uprawnienia prokuratora do rezygnacji $\mathrm{z}$ wniesienia oskarżenia do sądu

18 B. Henrich, Rechtsstaatliche Mindestgarantien im Strafverfahren, „Iura Helf” 2003 (3), s. 169.

${ }^{19}$ F. Casorla, La justice pénale de proximité, lentement mais sûrement, ,Revue pénitentiare et de droit pénal" 2004, nr 3, s. 661-664.

${ }^{20}$ Council of Europe, The Simplification of Criminal Justice, 2000, Recommendation No (87) 18, Council of Europe Strasbourg.

${ }^{21}$ A. Murzynowski, Mediacja $w$ toku postepowania przygotowawczego, w: S. Stachowiak (red.), Wspótczesny polski proces karny. Księga ofiarowana Profesorowi Tadeuszowi Nowakowi, Poznań 2002, s. 252-254. 
o popełnienie przestępstwa ściganego z urzędu, lecz czyn nie pozostanie bez jakiejkolwiek relacji ze strony organów ścigania, a oskarżony poniesie pewne skutki jego popełnienia, naprawiając szkodę, którą wyrządził ${ }^{22}$. Co więcej, należy odnotować, że nawet w państwach reprezentujących ściśle legalistyczne podejście do kwestii ścigania przestępstw, oddaje się coraz to większe uprawnienia $\mathrm{w}$ zakresie zaniechania ścigania przestępstw właśnie prokuratorom. Tym samym - kierując się potrzebą wprowadzenia szybszego i tańszego sposobu zwalczania drobnej i średniej przestępczości do polskiej ustawy karnej - należałoby rozważyć wprowadzenie instytucji „,warunkowego” umorzenia postępowania już na etapie śledztwa prokuratorskiego. Trzeba także zauważyć, że umorzenie postępowania już na etapie postępowania przygotowawczego bardziej spełniałoby postulat zwiększenia sprawności wymiaru sprawiedliwości i ekonomiki procesowej. Sytuacja ta byłaby korzystniejsza także dla stron postępowania, nie dochodziłoby bowiem do wniesienia aktu oskarżenia, a zaspokojenie potrzeb stron następowałoby już na etapie postępowania przygotowawczego.

Z całą stanowczością należy odmówić słuszności umorzeniu prokuratorskiemu w tym zakresie, w jakim przyznawałoby ono prokuratorom prawo merytorycznego decydowania w kwestii odpowiedzialności sprawcy czynu. Dlatego też słuszne jest, że na gruncie $§ 153$ a StPO i art. 41-1 CIC decyzja prokuratora $\mathrm{w}$ zakresie umorzenia postępowania wymaga ostatecznie zgody sądu. Mając także na uwadze konstytucyjna zasadę sądowego wymiaru sprawiedliwości, właściwym rozwiązaniem byłoby, aby także na gruncie polskiej ustawy postanowienie prokuratora o umorzeniu postępowania było zatwierdzane przez sąd. Słusznie wskazuje się w literaturze, że skoro we Francji, gdzie wyjątki na rzecz oportunizmu są największe, wprowadzono kontrolę sądową nad decyzjami dotyczącymi bezpośrednio materialnej odpowiedzialności sprawcy, to tym bardziej powinna być ona stosowana w kraju, w którym obowiązuje zasada legalizmu procesowego ${ }^{23}$. Decyzje prokuratora o umorzeniu postępowania podlegałaby kontroli sądu, także po to, aby zapobiec nadużywaniu tej instytucji.

Mając na uwadze europejska tendencję do ograniczania zasady legalizmu, należy przychylić się do przyznania słuszności idei wprowadzenia nowego rozwiązania, zmierzającego do zarezerwowania postępowania sądowego do poważniejszych spraw. Jednakże model zaprezentowany przez Komisję Kodyfikacyjną Prawa Karnego nie zasługuje na poparcie także $\mathrm{z}$ innego względu. A mianowicie, zakres czynów zabronionych, za które może „wykupić” się oskarżony, jest bardzo szeroki i obejmuje przestępstwa popełnione przeciwko wszystkim dobrom chronionym prawem. Co najważniejsze jednak, daje możliwość umorzenia postępowania $\mathrm{w}$ sprawach zagrożonych kara pozbawienia w wymiarze nawet 5 lat. Okoliczność ta sprawia, że taki sposób zakończenia postępowania może mieć miejsce także w sprawach, których społeczna szkodliwość jest na tyle wysoka, że uzasadnia wydanie orzeczenia o winie i karze oskarżonego. Należałoby zatem ograniczyć zakres tej instytucji

22 Ibidem.

${ }^{23}$ M. Rogacka-Rzewnicka, op. cit., s. 351. 
wyłącznie do drobnych przestępstw, w przypadku których zagrożenie karą nie przekracza 2 lat pozbawienia wolności. Przepis ten stanowiłby wówczas właściwe narzędzie do szybkiego zakończenia postępowania $\mathrm{w}$ sprawach drobnych i średnich przestępstw. Jednocześnie zbliżałby proponowaną konstrukcję do rozwiązania przyjętego w niemieckim kodeksie postępowania karnego, na gruncie której ma zastosowanie do przestępstw zagrożonych do roku pozbawienia wolności.

Egzemplifikując, wskazać należy, że zamiast proponowanej przez Komisję Kodyfikacyjną instytucji umorzenia postępowania na wniosek pokrzywdzonego polski ustawodawca rozważyć powinien wprowadzenie rozwiązania przyjętego już w niemieckim kodeksie postępowania karnego (§ 153a StPO). Za przyjęciem tego rozwiązania przemawia fakt, że w niemieckim kodeksie postępowania karnego regulacja ta obowiązuje już od 1975 r. i do dzisiaj jest pozytywnie oceniana w doktrynie niemieckiej ${ }^{24}$. Co prawda stanowi ona środek alternatywny dla wszczęcia postępowania karnego i tym samym nie stanowi sposobu zakończenia postępowania, tak jak miałoby to miejsce w przypadku proponowanego art. 59a k.k. Jednakże ten sposób odciążenia wymiaru sprawiedliwości wydaje się atrakcyjniejszy w porównaniu z propozycją naszej Komisji Kodyfikacyjnej. Do jej wad zaliczyć można jedynie to, że jej zastosowanie nie wymaga zgody pokrzywdzonego. Zakładając, że polska wersja mogłaby mieć zastosowanie w przypadku popełnienia poważniejszych przestępstw, uzyskanie zgody pokrzywdzonego na umorzenie postępowania wydaje się jednak niezastąpione.

dr Iwona Sepioto

Uniwersytet im. Adama Mickiewicza w Poznaniu

isepiolo@amu.edu.pl

RECONCILIATION OF THE VICTIM AND THE PERPETRATOR

AS A BASIS FOR DISCONTINUANCE OF CRIMINAL PROCEEDINGS IN LIGHT OF THE DRAFT AMENDMENT OF THE CRIMINAL LAW CODIFICATION COMMITTEE

Summary

The paper discusses the proposal to add article 59a to the Criminal Code of the following wording: 'At the victim's request, criminal proceedings regarding an offence punishable with imprisonment not exceeding 5 years may be discontinued if, before the commencement of judicial proceedings in the first instance the perpetrator has reconciled with his victim in the course of, in particular, mediation, and redressed the damage or otherwise provided compensation.' The proposed amendments give rise to a number of controversies. In particular, a question may be asked whether reconciliation of the perpetrator and the victim is sufficient to determine that the former need not be punished. The paper is an attempt to evaluate the proposal put forward by the Codification Committee.

${ }^{24}$ A. Ignor, H. Matt, Integration und Offenheit im Strafprozeß Vorschläge zu einer Reform des Strafverfahrens, StV 2002 (2), s. 107, za: M. Rogacka-Rzewnicka, Oportunizm ścigania przestęstw - wybrane aspekty teoretyczne, „Prokuratura i Prawo” 2004, nr 11-12, s. 56. 
Copyright of Journal of Law, Economics and Sociology is the property of Faculty of Law and Administration of Adam Mickiewicz University in Poznan and its content may not be copied or emailed to multiple sites or posted to a listserv without the copyright holder's express written permission. However, users may print, download, or email articles for individual use.

Właścicielem praw autorskich do „Ruchu Prawniczego, Ekonomicznego i Socjologicznego” jest Wydział Prawa i Administracji Uniwersytetu im. Adama Mickiewicza w Poznaniu. Zawartość czasopisma nie może być kopiowana, przesyłana do innych stron internetowych bądź zamieszczana na blogach bez pisemnej zgody wydawcy. Niemniej artykuły można drukować, kopiować lub przesyłać w formie elektronicznej na własny użytek. 